\title{
Ilha Grande, one of the locations with the most records of bat species (Mammalia, Chiroptera) in Rio de Janeiro state: results of a long-term ecological study
}

\author{
Luciana Moraes Costa ${ }^{1,5}$; Elizabete Captivo Lourenço ${ }^{1,6}$; Daniel de Abreu Damasceno Júnior ${ }^{1,7}$; Daniela Dias ${ }^{2}$; \\ Carlos Eduardo Lustosa Esbérard ${ }^{3}$; Tássia Jordão-Nogueira ${ }^{1,8}$; Glauce Melo ${ }^{1,4,9}$ \& Helena Godoy Bergallo ${ }^{1,10}$
}

1 Universidade do Estado do Rio de Janeiro (UERJ), Instituto de Biologia Roberto Alcântara Gomes (IBRAG), Departamento de Ecologia (DECOL), Laboratório de Ecologia de Mamíferos. Rio de Janeiro, RJ, Brasil.

2 Fundação Oswaldo Cruz (FIOCRUZ), Instituto Oswaldo Cruz (IOC), Laboratório de Biologia e Parasitologia de Mamíferos Silvestres Reservatórios. Rio de Janeiro, RJ, Brasil. ORCID: http://orcid.org/0000-0001-5921-4909. E-mail: diasdani74@gmail.com

3 Universidade Federal Rural do Rio de Janeiro (UFRRJ), Instituto de Ciências Biológicas e da Saúde (ICBS), Departamento de Biologia Animal, Laboratório de Diversidade de Morcegos. Seropédica, RJ, Brasil. ORCID: http://orcid.org/0000-0002-6389-190X. E-mail: ceesberard@gmail.com

${ }^{4}$ Hospital Universitário Antônio Pedro. Niterói, RJ, Brasil.

${ }^{5}$ ORCID: http://orcid.org/0000-0001-8080-4954. E-mail: costalucianam@gmail.com

${ }^{6}$ ORCID: http://orcid.org/0000-0002-6136-708X. E-mail: beteclouren1205@yahoo.com.br (corresponding author)

7 ORCID: http://orcid.org/0000-0002-5230-8918. E-mail: danjunior.work@gmail.com

${ }^{8}$ ORCID: http://orcid.org/0000-0003-0448-4615.E-mail: tassiajordao@yahoo.com.br

${ }^{9}$ ORCID: http://orcid.org/0000-0001-6001-0866. E-mail: g.attack2015@gmail.com

${ }^{10}$ ORCID: http://orcid.org/0000-0001-9771-965X. E-mail: nena.bergallo@gmail.com

\begin{abstract}
Faunal inventories provide quantitative and qualitative data for different sites and are relevant sources of information for identifying areas of high species richness and endemism. Biological collections are important in this context for increasing the precision of species identification. The objectives of this study were to update the list of bat species of Illha Grande by analyzing specimens in zoological collections as well as records obtained in areas where no such studies had been undertaken before; to compare five different studies conducted on Ilha Grande using mist net sampling; and to compare the results of studies on Ilha Grande with sampling results from other areas in Rio de Janeiro state. The occurrence of 36 bat species was confirmed for Ilha Grande. Five studies on Ilha Grande formerly conducted by the authors were compared with 34 fauna inventories in Rio de Janeiro state. The studies on Ilha Grande had distinct objectives and sampling techniques applied to different locations in the same area. Ilha Grande is one of the regions in Rio de Janeiro state with more bat records both in terms of abundance and number of species, as well as one of the areas of highest bat capture effort.
\end{abstract}

Keywords. Atlantic Forest; Inventory; RAPELD; Richness; Zoological collections.

\section{INTRODUCTION}

Knowledge on biological diversity is considered essential for planning conservation actions, as these depend on understanding species distribution and systematics as well as aspects related to community ecology, demography and natural history (Santos, 2003; Silveira et al., 2010). Fauna inventories provide quantitative and qualitative data (Owen, 2000), therefore being relevant sources of information for identifying areas of high richness and endemism (Remsen, 1994; Blackburn \& Gaston, 1998; Myers et al., 2000). Species inven- tories form a substantial part of studies on mammals in Brazil (Brito et al., 2009).

The Order Chiroptera represents the second most studied taxon among mammals in Brazil (Brito et al., 2009). Bats are considered well studied in Atlantic Forest ecosystems (Bernard et al., 2011). There is a long history of scientific inventories in the biome, a larger concentration of researchers and scientific institutions, and more financial resources compared with other regions in Brazil (see Lewinsohn \& Prado, 2005; Brito et al., 2009). Although survey gaps remain in several regions in the country, bats may be considered well 
studied in Rio de Janeiro state, in southeastern Brazil (Bergallo et al., 2003; Peracchi \& Nogueira, 2010; Stevens, 2013). Secondary studies in this region can therefore be useful to synthesize data in search of new evidence.

Different techniques may be used in chiropterofauna inventories. Capture methods used in inventories must be efficient in capturing the largest number of species. The method most commonly used in the Neotropical region for bat capture is to set mist nets in probable bat flight routes in the forest undergrowth (Kunz \& Kurta, 1988; Estrada et al., 2004). Mist nets are efficient for capturing bats in the Phyllostomidae family, especially for frugivore bats (Sipinski \& Reis, 1995; Pedro \& Taddei, 1997; Kalko, 1998). The efficiency of the method is low for insectivore bats in families Emballonuridae, Thyropteridae, Vespertilionidae, and Molossidae (Voss \& Emmons, 1996; Simmons \& Voss, 1998), as insectivore species tend to fly higher and avoid the nets by using echolocation (Kunz \& Kurta, 1988; Voss \& Emmons, 1996).

The selective quality of mist nets can be minimized by sampling design. Alternatives have been used in different studies to increase capture of insectivore bats or of bat species that fly above the forest undergrowth. Mist nets are set in the higher forest strata or above water (e.g., Carvalho \& Fabián, 2011; Costa et al., 2012). Sampling design can also influence bat abundance, not only species richness, and be directed at certain species or groups of species. Mist nets set near fruit-bearing trees would increase capture of frugivorous species, for example (Kalko, 1998). Methodological variations can lead to detecting more species or capturing more bats in an area, but total local density may interfere with capture rates (e.g., Fleming, 1988). Capture effort is another relevant variable for increasing the knowledge of species in an area, being strictly related to richness (Bergallo et al., 2003).

Ilha Grande is recognized as one of the areas of highest bat richness and abundance in the state of Rio de Janeiro due to intensive capture efforts in different regions (see Bergallo et al., 2003; Esbérard et al., 2006). The first list of bat species of Ilha Grande, compiled in 1988, included seven species (Fernandez et al., 1988). Later Esbérard et al. (2006) updated these records, listing 36 species. However, some areas on the island, especially in the forest interior and at elevations higher than 250 meters, had not been well studied before 2014 despite high capture efforts in other areas (Esbérard et al., 2006). Additionally, new bat species have been described for Ilha Grande in recent years and taxonomic issues on Chiroptera in Brazil were resolved. For these reasons, a taxonomic review of bats of Ilha Grande was needed to provide a more precise estimate of bat diversity on the island. The objectives of this study were, therefore, to (i) compile an updated list of bat species of Ilha Grande by conducting studies in areas that had not been well studied and reviewing the taxonomic identification of voucher specimens; (ii) compare different studies formerly conducted on Ilha Grande; (iii) compare studies conducted on Ilha Grande with studies in other areas in Rio de Janeiro state.

\section{MATERIAL AND METHODS}

\section{Study area}

Ilha Grande is located in Ilha Grande Bay, in the municipality of Angra dos Reis. It is the third largest island in Brazil (INEA, 2020), and the largest in Rio de Janeiro state. The shortest distance to the continent is approximately $2 \mathrm{~km}$ (Araújo \& Oliveira, 1988). Protected areas are established on $156 \mathrm{~km}^{2}$ ( $81 \%$ of the insular surface) of the total $193 \mathrm{~km}^{2}$ of Ilha Grande (Ilha Grande State Park and Praia do Sul Biological Reserve, INEA, 2013) in the category of strict protection. The climate is tropical, hot and humid, subject to rainfall all year round, with higher concentration in the summer and lower in winter, and no dry season (INEA, 2013). The variation in average temperature is low throughout the year. July is the coldest month $\left(20.2^{\circ} \mathrm{C}\right)$, and February, the hottest $\left(26.4^{\circ} \mathrm{C}\right)$ (INEA, 2013). The forests on Ilha Grande are classified as Dense Ombrophilous Forest (Atlantic Forest) in the Brazilian Classification System (INEA, 2013). Dense secondary forests in intermediate and advanced stages of succession cover about $80 \%$ of the island. The remaining areas are forests in early successional stages, coastal scrub (restinga), vegetation on rock outcrops, and mangroves (INEA, 2013). Ilha Grande contains some of the best conserved remnants of the Atlantic Forest biome in Brazil, being therefore considered an ecological sanctuary. The relevance of local ecosystems led to the inclusion of Ilha Grande in the Atlantic Forest Biosphere Reserve in 1992 (INEA, 2020). It was more recently declared a UNESCO Natural Heritage Site on 05 July, 2019.

\section{Data collection}

Bat capture and data generation are results of different projects of the Mammal Ecology Lab (Laboratório de Ecologia de Mamíferos - LEMA) of the Rio de Janeiro State University (Universidade do Estado do Rio de Janeiro - UERJ). These five studies on bats conducted on Ilha Grande were not published independently in scientific journals. Some of the data gathered in studies 1, 2, 3, and 4 (described below) were included in the study by Esbérard et al. (2006). While other exclusive results by Esbérard et al. (2006) were not used in the present study, as they are not data from LEMA.

The bats captured in all studies were released on the same site of capture. Bats were initially identified in the field with the use of field guides and identification keys available in the scientific literature (mainly, Emmons \& Feer, 1997; Gregorin \& Taddei, 2002; Reis et al., 2007; Gardner, 2008; Reis et al., 2013). A few individuals of each species were collected for voucher material (see Table 1). Voucher specimens captured in studies 1, 2, 3, and 4 were deposited in the collection of the old Urban Bats Project (Projeto Morcegos Urbanos), currently the reference collection of the Bat Diversity Lab (Laboratório de Diversidade de Morcegos - LADIM) of the Federal Rural University of Rio de Janeiro (Processes 1785/89-IBAMA 
Table 1. Updated list of bat species of llha Grande, Angra dos Reis, Rio de Janeiro state, Brazil, with reference to voucher specimens. Nomenclature and taxonomic arrangement according to Garbino et al. (2020).

\begin{tabular}{|c|c|}
\hline TAXA & VOUCHER MATERIAL \\
\hline \multicolumn{2}{|l|}{ Family Emballonuridae } \\
\hline Peropteryx macrotis (Wagner, 1843) & LADIM 3836 \\
\hline \multicolumn{2}{|l|}{ Family Phyllostomidae } \\
\hline Micronycteris microtis Miller, 1898 & LADIM 3466, 4019; ALP 10843 \\
\hline Desmodus rotundus (É. Geoffroy, 1810) & ALP 10931 \\
\hline Chrotopterus auritus (Peters, 1856) & ALP 10842 \\
\hline Phyllostomus hastatus (Pallas, 1767) & LADIM 4045 \\
\hline Tonatia bidens (Spix, 1823) & ALP 10844,10943 \\
\hline Trachops cirrhosus (Spix, 1823) & ALP 10580 \\
\hline Anoura caudifer (É. Geoffroy, 1818) & ALP 11026, 11045 \\
\hline Anoura geoffroyi Gray, 1838 & ALP 10939 \\
\hline Glossophaga soricina (Pallas, 1766) & ALP 10923 \\
\hline Lonchophylla peracchii Dias, Esbérard e Moratelli, 2013 & ALP 10924 \\
\hline Carollia perspicillata (Linnaeus, 1758) & ALP 10845,11023 \\
\hline Glyphonycteris sylvestris Thomas, $1896^{*}$ & ALP 10940 \\
\hline Artibeus cinereus (Gervais, 1856) & ALP 11038 \\
\hline Artibeus fimbriatus Gray, 1838 & $\begin{array}{l}\text { LADIM 3823, 4016, 4017; ALP } \\
\text { 10840, } 10851\end{array}$ \\
\hline Artibeus lituratus (Olfers, 1818) & LADIM 4031; ALP 10937 \\
\hline Artibeus obscurus Schinz, 1821 & $\begin{array}{l}\text { LADIM 3916, 3914, 3920;;ALP } \\
10838,10919\end{array}$ \\
\hline Chiroderma doriae Thomas, 1891 & LADIM 3945; ALP 10852 \\
\hline Chiroderma villosum Peters, 1860 & ALP 11039 \\
\hline Platyrrhinus lineatus (É. Geoffroy, 1810) & $\begin{array}{l}\text { LADIM 3997, 4023; ALP 11052, } \\
11053\end{array}$ \\
\hline Platyrrhinus recifinus (Thomas, 1901)* & LADIM 4229; ALP 10925, 10942 \\
\hline Pygoderma bilabiatum (Wagner, 1843) & ALP 11048 \\
\hline Sturnira lilium (É. Geoffroy, 1810) & ALP 10846 \\
\hline Sturnira tildae de la Torre, 1959 & ALP 10848 \\
\hline Vampyressa pusilla (Wagner, 1843) & ALP 10928, 10944 \\
\hline Vampyrodes caraccioli (Thomas, 1889)* & ALP 10841 \\
\hline Family Noctilionidae & \\
\hline Noctilio leporinus (Linnaeus, 1758) & LADIM 1072 \\
\hline Family Furipteridae & \\
\hline Furipterus horrens (Cuvier, 1828)** & LADIM 3625 \\
\hline Family Molossidae & \\
\hline Molossus fluminensis Lataste, 1891 & LADIM 1011 \\
\hline Molossus molossus (Pallas, 1766) & ALP 11031 \\
\hline Nyctinomops laticaudata (É. Geoffroy, 1805)** & LADIM 3887; ALP 11056 \\
\hline Family Vespertilionidae & \\
\hline Lasiurus ega (Gervais, 1856) & LADIM 3679 \\
\hline Myotis albescens (É. Geoffroy, 1906)** & ALP 10918 \\
\hline Myotis izecksohni Moratelli, Peracchi, Dias \& Oliveira, 2011* & ALP 11049 \\
\hline Myotis nigricans (Schinz, 1821) & LADIM 3704; ALP 11044, 11047 \\
\hline Myotis riparius Handley, $1960^{*}$ & ALP 10839, 10847 \\
\hline Species added to the bat list of Illa Grande. & \\
\hline $\begin{array}{l}\text { Species registered by Esbérard et al. (2006) and } \\
\text { detailed in the present study. }\end{array}$ & \\
\hline $\begin{array}{l}\text { LADIM }=\text { Reference collection of the Bat Diversity Lab, Feder } \\
A L P=\text { Reference collection of the Mastozoology Lab, Feder }\end{array}$ & $\begin{array}{l}\text { ral Rural University of Rio de Janeiro. } \\
\text { eral Rural University of Rio de Janeiro. }\end{array}$ \\
\hline
\end{tabular}

and SISBIO-10356-1). The voucher material of study 5 was deposited in the reference collection of the Mastozoology Lab (Laboratório de Mastozoologia Dr. Adriano Lúcio Peracchi - ALP) of the Federal Rural University of Rio de Janeiro (Universidade Federal Rural do Rio de Janeiro UFRRJ) (Permanent IBAMA License № 12548 and № 10361; SISBIO № 45702-4; INEA № 63/2015; CEUA № 008/2018).
Fieldwork for study 1 was conducted during three consecutive nights per month between January, 1998, and December, 1999, totaling 72 survey nights. Two to five mist nets were set every night (sizes varying from $6 \times 3$ meters to $12 \times 3$ meters) and deployed for a period of six hours. Capture effort was estimated at a minimum of 15,552 h.m ${ }^{2}$ and a maximum of 77,760 h.m ${ }^{2}$ (Straube \& Bianconi, 2002), with an average of 46,656 h.m². The sampling sites (one per night) were the Caxadaço trail, Parnaioca trail and Dois Rios Village (Fig. 1). Sampling was carried out in well conserved habitats and under varied climatic conditions that included wind and rain, and covered all phases of the lunar cycle. Mist nets were set in areas with higher likelihood of bat capture according to recommendations by Kunz \& Kurta (1988), such as close to the entrance of caves, over rivers, along trails, faults, rocky formations, tree hollows, and under flowering or fruit-bearing trees.

Fieldwork for study 2 was conducted between May, 2001, and April, 2002. Six field surveys were carried out, each one during one, three or four nights, totaling 19 survey nights. Two to five mist nets (sizes varying from $7 \times 3$ meters to $12 \times 3$ meters) were deployed between four and seven hours from twilight, totaling 17,518 h.m ${ }^{2}$ of capture effort. The sampling sites were located in Dois Rios Village, Parnaioca Village, Abraão Village and on Praia Grande de Palmas (Fig. 1). The position of mist nets was defined using the same criteria as in study 1 .

Fieldwork for study 3 was conducted between September, 2002, and August, 2005, with sampling undertaken in three consecutive nights, totaling 33 survey nights. Mist nets were set in the same position during the three nights of the survey. Six mist nets were deployed every night $(12 \times 3$ meters $)$ from twilight to dawn, totaling 85,536 h.m ${ }^{2}$ of capture effort. Eleven areas were covered: Matariz Village, Saco do Céu, Enseada das Estrelas, Abraão Village, Praia Grande de Palmas, Farol dos Castelhanos, Praia de Lopes Mendes, Caxadaço, Dois Rios Village, Dois Rios Village trail - Parnaioca, Parnaioca

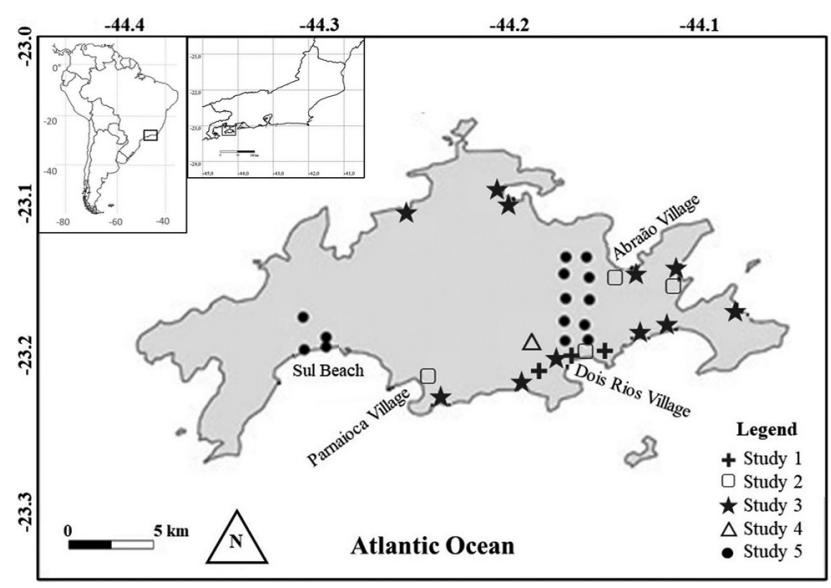

Figure 1. Map of llha Grande with sampling points of the five studies described in this paper, conducted between 1998 and 2018 on Ilha Grande, Angra dos Reis, Rio de Janeiro state, Brazil. A map of South America is shown, detailing the location of the state of Rio de Janeiro, in southeastern Brazil, while in the enlargement is shown the state of Rio de Janeiro detailing the location of llha Grande. 
Village (Fig. 1). Sites were chosen by drawing sampling points at random on a virtual grid covering the entire area of Ilha Grande in order to generate data from various areas, not only from sites that favored bat flight routes. Mist nets were set in line as much as possible, with the center of the line on the coordinate of the sampling point. No phases of the lunar cycle were privileged in this study.

Fieldwork for study 4 was conducted between November, 2004 and January, 2007, totaling 31 survey nights. Mist nets were set in the tree canopy and in the understory. Nets were fastened in the canopy with a set of ropes and pulleys (Humphrey et al., 1968; Vecchi \& Alves, 2015), while nets in the understory were set underneath the ones above. The position of mist nets was not changed throughout the period of the survey. Three mist nets $(12 \times 3$ meters) were deployed in the canopy and three in the understory every night, totaling a capture effort of 82,944 h.m ${ }^{2}, 40,176$ h.m ${ }^{2}$ in the canopy and 40,176 h. $\mathrm{m}^{2}$ in the understory. All bats were individually marked with a colorful bead collar on a nylon string and a unique code, following our own methodology. The sampling site at the end of the Jararaca trail in Dois Rios Village (Fig. 1) was located at 240 meters altitude a.s.l. (Vecchi \& Alves, 2015). Canopy height varied from 10 to 35 meters, or 23 meters on average ( \pm 5.8 metros), although a few emergent trees reached 40 meters (Vecchi \& Alves, 2015).

Fieldwork for study 5 was conducted between December, 2014, and August, 2018, totaling 56 survey nights. Bats were captured with 13 mist nets $(10 \times 3$ meters, 19 mm mesh, Ecotone ${ }^{\circledR}$ 719/10) deployed before twilight and closed before dawn, totaling 257,790 h. $\mathrm{m}^{2}$ of capture effort. Captured bats were marked with plastic collars with closed bands, each individual having a unique number. Small and young individuals were marked by piercing the dactylopatagium (Bonaccorso \& Smythe, 1972) to facilitate identification in the short term in case of recapture. The methodology of uniform distribution plots (RAPELD - acronym in Portuguese for Rapid Assessment in Long-Term Ecological Research Sites) was adapted to long-term ecological research sites (Magnusson et al., 2005). A total of 14 uniform distribution plots were assessed (Fig. 1), each 250 meters long along contour lines. Ten plots were located in the eastern part of the island, in Ilha Grande State Park, between Abraão and Dois Rios Villages, in Submontane and Montane Dense Ombrophilous Forest. Four plots were located in the western side of the island, in the Praia do Sul State Biological Reserve, in Submontane Ombrophilous Forest and coastal scrub forest (mata de restinga), between beaches Longa and Sul. Plots were located from sea level to 692 meters of altitude. No mist nets were set close to known refuges, neither over water bodies or near fruit-bearing plants. Sampling dates were defined regardless of lunar phases.

A species accumulation curve was built for each of the studies to plot the accumulated number of captures ( $X$ axis) per accumulated species richness ( $Y$ axis). The Jaccard Similarity Index was calculated with the Past 2.1 software (Hammer et al., 2001) to compare the five studies conducted on Ilha Grande.

\section{Comparison between studies on Ilha Grande and other studies in Rio de Janeiro state}

The following sources were consulted in our literature review: CAPES database of non-published studies (http:// www.capes.gov.br/servicos/banco-de-teses), Scientific Electronic Library Online (SciELO, http://www.scielo.org), Web of Science (WoS, http://www.webofknowledge. com), Google Scholar (https://scholar.google.com.br), and specialized journals not indexed in Scielo or Web of Science. The literature search was concluded in January, 2019. The following keywords were used in the search: "Chiroptera Rio de Janeiro", "quiróptero Rio de Janeiro", "morcego Rio de Janeiro" and "bat Rio de Janeiro".

Only studies that provide species lists with respective numbers of captured individuals were selected. We considered abundance as the sum of capture and recapture because some of the studies did not provide separate data. As not all studies discriminate the numbers of captures near refuges, captures in refuges were not excluded from the analyses, but the studies that mention this method of capture were marked. Inventories that did not use standardized capture methods according to Straube \& Bianconi (2002) (h.m²) were not used in the analysis of capture efforts.

In order to compare richness, capture number and capture effort between studies conducted on Ilha Grande and other studies in Rio de Janeiro state, only data of species in the family Phyllostomidae were used because capturing bats with mist nets in the understory is more efficient for this family (Sipinski \& Reis, 1995; Pedro \& Taddei, 1997; Kalko, 1998). Two simple linear regression analyses were performed, the first to compare Phyllostomidae richness with number of captures in different studies in Rio de Janeiro state; and the second to compare Phyllostomidae richness and capture effort between the different studies. The program Systat 13.0 was used for these analyses.

\section{RESULTS}

\section{Updated list of bat species and capture results from five different studies of Ilha Grande}

We confirmed the occurrence of 36 bat species on Ilha Grande (Table 1). We add five species to the Ilha Grande bat list: Glyphonycteris sylvestris, Platyrrhinus recifinus, Vampyrodes caraccioli, Myotis izecksohni, and M. riparius. We removed seven species from the previous list: Artibeus planirostris, Lonchophylla mordax, Lonchophylla bokermanni, Micronycteris minuta, Micronycteris megalotis, Uroderma magnirostrum, and Nyctinomops macrotis.

Considering the five studies together, a total of 2,763 individuals of 32 species in 23 genera and five families were captured. The most abundant species on the island 
Table 2. Bat abundance in five studies conducted between 1998 and 2018 on llha Grande, Angra dos Reis, Rio de Janeiro state, Brazil. In parentheses, number of recaptures in studies that cite this data. Total capture number includes recapture.

\begin{tabular}{|c|c|c|c|c|c|c|}
\hline Taxa & Study 1 (1998-1999) & Study 2 (2001-2002) & Study 3 (2002-2005) & Study 4 (2004-2007) & Study 5 (2014-2018) & TOTAL \\
\hline \multicolumn{7}{|l|}{ Family Emballonuridae } \\
\hline Peropteryx macrotis & 0 & 0 & 1 & 0 & 0 & 1 \\
\hline \multicolumn{7}{|l|}{ Family Phyllostomidae } \\
\hline Micronycteris microtis & 2 & 0 & 3 & 0 & 13 & 18 \\
\hline Desmodus rotundus & 13 & 2 & 16 & 0 & 3 & 34 \\
\hline Chrotopterus auritus & 0 & 0 & 0 & 1 & 5 & 6 \\
\hline Phyllostomus hastatus & 4 & 0 & 25 & 0 & 0 & 29 \\
\hline Tonatia bidens & 16 & 7 & 9 & 2 & 12 & 46 \\
\hline Trachops cirrhosus & 4 & 3 & 8 & 0 & 16 & 31 \\
\hline Anoura caudifer & 19 & 6 & 9 & 1 & $6(1)$ & 42 \\
\hline Anoura geoffroyi & 0 & 0 & 0 & 0 & 6 & 6 \\
\hline Glossophaga soricina & 16 & 0 & 4 & 1 & 4 & 25 \\
\hline Lonchophylla peracchii & 8 & 2 & 4 & 3 & 7 & 24 \\
\hline Carollia perspicillata & 225 & 65 & 161 & 18 & $239(27)$ & 735 \\
\hline Glyphonycteris sylvestris & 0 & 0 & 0 & 0 & 2 & 2 \\
\hline Artibeus cinereus & 0 & 0 & 0 & 2 & 4 & 6 \\
\hline Artibeus fimbriatus & 203 & 25 & 81 & $84(8)$ & $80(4)$ & 485 \\
\hline Artibeus lituratus & 33 & 3 & 31 & $23(1)$ & 25 & 116 \\
\hline Artibeus obscurus & 139 & 46 & 99 & $32(3)$ & $148(6)$ & 473 \\
\hline Artibeus spp. & 41 & 4 & 8 & $17(1)$ & 0 & 71 \\
\hline Chiroderma doriae & 3 & 1 & 7 & 7 & 4 & 22 \\
\hline Chiroderma villosum & 1 & 0 & 2 & 0 & 2 & 5 \\
\hline Platyrrhinus lineatus & 13 & 5 & 9 & 3 & 8 & 38 \\
\hline Platyrrhinus recifinus & 0 & 0 & 0 & 3 & 8 & 11 \\
\hline Pygoderma bilabiatum & 1 & 0 & 1 & 10 & 0 & 12 \\
\hline Sturnira lilium & 161 & 33 & 76 & 11 & 4 & 285 \\
\hline Sturnira tildae & 0 & 0 & 0 & 2 & 5 & 7 \\
\hline Vampyressa pusilla & 0 & 4 & 7 & 2 & 4 & 17 \\
\hline Vampyrodes caraccioli & 0 & 0 & 0 & 0 & 3 & 3 \\
\hline \multicolumn{7}{|l|}{ Family Noctilionidae } \\
\hline Noctilio leporinus & 1 & 33 & 42 & 0 & 0 & 76 \\
\hline \multicolumn{7}{|l|}{ Family Molossidae } \\
\hline Molossus fluminensis & 0 & 2 & 2 & 0 & 0 & 4 \\
\hline Molossus molossus & 4 & 16 & 42 & 0 & 0 & 62 \\
\hline \multicolumn{7}{|l|}{ Family Vespertilionidae } \\
\hline Myotis izecksohni & 0 & 0 & 0 & 0 & 1 & 1 \\
\hline Myotis nigricans & 12 & 10 & 18 & 4 & 1 & 45 \\
\hline Myotis riparius & 0 & 0 & 0 & 0 & 25 & 25 \\
\hline Total capture & 919 & 267 & 665 & $226(13)$ & $635(38)$ & 2.763 \\
\hline Accumulated capture & 919 & 1.186 & 1.851 & 2.090 & 2.763 & 一 \\
\hline Total species & 20 & 17 & 23 & 18 & 26 & 32 \\
\hline Accumulated species & 20 & 22 & 23 & 27 & 32 & 一 \\
\hline Exclusive species & 0 & 0 & 1 & 0 & 5 & 一 \\
\hline Capture effort (h.m²) & 46.656 & 17.518 & 85.536 & 82.944 & 257.790 & 490.444 \\
\hline Capture efficiency* & 0,020 & 0,015 & 0,008 & 0,003 & 0,003 & 0,006 \\
\hline
\end{tabular}

* $=$ Total capture divided by capture effort.

were C. perspicillata, with 735 captures, and A. fimbriatus, with 485 captures. Bats of two species were only captured once, $P$. macrotis and M. izecksohni. Eleven species were common to the five studies: $C$. perspicillata, $A$. fimbriatus, Sturnira lilium, A. obscurus, Artibeus lituratus, A. caudifer, T. bidens, Platyrrhinus lineatus, M. nigricans, Lonchophylla peracchii, and C. doriae (Table 2 ).

Chronologically, 20 species were registered in the first study; two species added from the second study, and only one species from the third study. Four more species were added from study 4, with C. auritus, Artibeus cinere$u s$, and $P$. recifinus captured exclusively in mist nets in the canopy, and Sturnira tildae only in a mist net at ground level. Five other species were added from study 5 . All five studies have therefore contributed species for the bat list of Ilha Grande (Table 2).

The Jaccard Similarity Index between the five studies on Ilha Grande demonstrated a variation of $\mathrm{Cj}=0.48$ to 0.87 . Studies 1 and 3 had more similar results (87\%), followed by studies 2 and 3 (74\%) (Table 3). 
Table 3. Jaccard Similarity Index between five different studies conducted between 1998 and 2018 on Ilha Grande, Angra dos Reis, Rio de Janeiro state, Brazil.

\begin{tabular}{lccccc}
\hline & Study 1 & Study 2 & Study 3 & Study 4 & Study 5 \\
\hline Study 1 & 1.00 & & & & \\
Study 2 & 0.68 & 1.00 & & & \\
Study 3 & 0.87 & 0.74 & 1.00 & & \\
Study 4 & 0.52 & 0.52 & 0.52 & 1.00 & \\
Study 5 & 0.53 & 0.48 & 0.53 & 0.63 & 1.00 \\
\hline
\end{tabular}

\section{Comparison between studies on Ilha Grande and other studies in Rio de Janeiro state}

A total of 39 studies containing lists of bat species in Rio de Janeiro state were reviewed (Table 4 and Fig. 2). The best studied location was Maciço da Tijuca, with six sampling sites. Five studies conducted on Ilha Grande were assessed. Two studies conducted at different periods in time were found for each of the locations Pedra Branca State Park and Tinguá Biological Reserve. One single inventory was found for each of the other locations.

The highest number of Phyllostomidae bat species was registered in the Tinguá Biological Reserve, with 25 species in the family (Table 4, Figs. 3A and 3B). At the same time, it accounted for the highest capture effort of all studies (268,473 h.m ${ }^{2}$ ) (Table 4, Figs. 3A and 3B). Study 5 on Ilha Grande is among the richest in Phyllostomidae, with 23 species (Table 4, Figs. 3A and 3B). The study with highest capture success was conducted at Quinta da Boa Vista, with 2,994 captures (Table 4, Fig. 3A). The linear regression between capture number and species richness was significant $\left(r^{2}=0.337 ; F=4.732 ; p=0.036\right)$, but the best fit was generated from a quadratic model $\left(r^{2}=0.648\right.$ - Fig. 3A). The linear regression between capture effort and richness was also significant, as well as positive $\left(r^{2}=0.546 ; F=24.078 ; p<0.001\right.$, Fig. 3B). This confirmed that the higher the number of captures and capture effort, the higher the richness encountered.

\section{DISCUSSION}

The confirmation that 36 bat species occur on Ilha Grande implies that the island hosts $18 \%$ of the bat species known in Brazil (Garbino et al., 2020), 37\% of the species in the Atlantic Forest (Muylaert et al., 2017), and 46\% of the species known in Rio de Janeiro state (Peracchi \& Nogueira, 2010; Moratelli et al., 2011; Dias et al., 2013; Delciellos et al., 2018).

Species lists must be regularly updated because new species are continually described and recorded in Brazil due to taxonomic revisions (e.g., Moratelli et al., 2011; Dias et al., 2013; Garbino et al., 2020). In addition, there are species that are difficult to identify and can be confused with other species such as G. sylvestris (Nogueira et al., 2007) and species of the genus Myotis (LópezGonzález et al., 2001; Moratelli et al., 2011).

Myotis izecksohni was described after publication of the first list of bat species of Ilha Grande (Esbérard et al.,

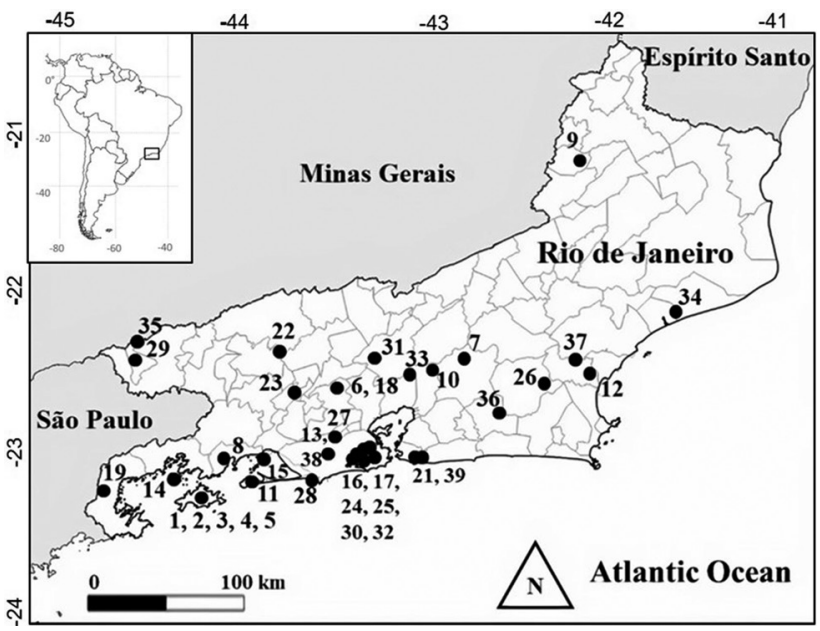

Figure 2. Locations in Rio de Janeiro state where bat inventories have been conducted. Numbers correspond to locations in Table 4. A map of South America is shown, detailing the location of the state of Rio de Janeiro in southeastern Brazil.

2006). Records of M. izecksohni have shown that it occurs between 600 and 1,300 meters a.s.l. (Moratelli et al., 2011; Reis et al., 2013; Dias et al., 2015). Bats of this species were captured during study 5 on Ilha Grande at 408 meters a.s.l., which indicates that it can occur at lower altitudes than formerly stated.

Based on taxonomic reviews of bat voucher material collected in studies by Esberard et al. (2006), the occurrence of seven species was not confirmed on Ilha Grande. They were therefore removed from our list. Some species, such as A. planirostris, M. minuta, N. macrotis and U. magnirostrum, are reported for the Costa Verde region, in the municipalities of Mangaratiba or Angra dos Reis (Bolzan et al., 2010; Delciellos et al., 2018). Specimens registered by Esbérard et al. (2006) as M. megalotis correspond to M. microtis. Specimens formerly identified on the island as L. mordax and L. bokermanni correspond to L. peracchii, the only species of Lonchophyllinae registered in the state of Rio de Janeiro (see Dias et al., 2013).

The five studies conducted by the authors on Ilha Grande and described in this paper amount to a total capture effort of 490,444 h.m², one of the largest ever applied to a single area in Rio de Janeiro state. Considering all five studies, the species more often captured were $C$. perspicillata and $A$. fimbriatus, which together represented almost half the total captures (44,15\%). These two most abundant species on Ilha Grande are also among the most frequent and most captured bat species in the Atlantic Forest domain (Muylaert et al., 2017). As Esbérard et al. (2006) had already observed, the record of $A$. fimbriatus as the second most abundant species differs from other locations surveyed in Rio de Janeiro state, where A. lituratus is most often more abundant (e.g., Dias et al., 2002; Luz et al., 2011a; Esbérard et al., 2013; Lourenço et al., 2014; Souza et al., 2015).

Although the five studies conducted on the island were based on the use of mist nets, the sampling points and some criteria for defining the location of these points differed. In studies 1 and 2, mist nets were set in probable bat flight routes (Kunz \& Kurta, 1988), resulting 

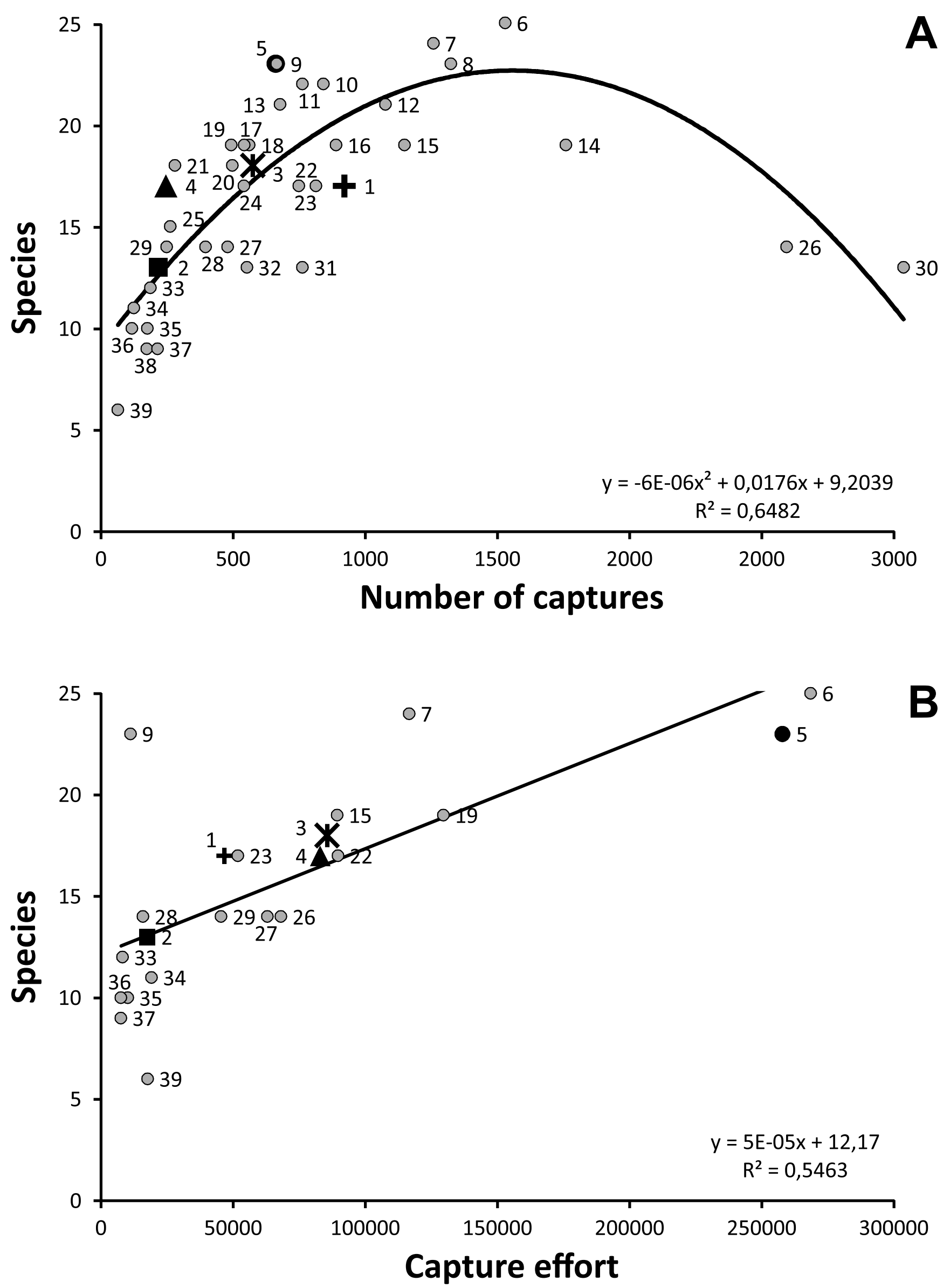

Figure 3. Relationship between number of species in the Phyllostomidae family (A) and number of captures in the Phyllostomidae family, (B) and capture effort $\left(\right.$ h. $\left.\mathrm{m}^{2}\right)$ in bat inventories in Rio de Janeiro state. Numbers correspond to locations listed in Table IV. Dots: cross = study 1 on Ilha Grande; square = study 2 on Ilha Grande; star = study 3 on Ilha Grande; triangle = study 4 on Ilha Grande; black circle = study 5 on Ilha Grande; grey circle = other studies in Rio de Janeiro state. 
Table 4. Bat studies in Rio de Janeiro state, number of species and number of captures in the family Phyllostomidae, capture effort (according to Straube \& Bianconi, 2002), latitude and longitude of each site, and respective references.

\begin{tabular}{|c|c|c|c|c|c|c|c|}
\hline № & Inventories & № species Phyllostomidae & Capture & Effort (h.m²) & Latitude & Longitude & Reference \\
\hline 1 & Ilha Grande (Study 1) & 17 & 902 & 46.656 & -23.148417 & -44.246978 & This study \\
\hline 2 & Ilha Grande (Study 2) & 13 & 206 & 17.518 & -23.148417 & -44.246978 & This study \\
\hline 3 & Illha Grande (Study 3) & 18 & 560 & 85.536 & -23.148417 & -44.246978 & This study \\
\hline 4 & Ilha Grande (Study 4) & 17 & 235 & 82.944 & -23.148417 & -44.246978 & This study \\
\hline 5 & Ilha Grande (Study 5) & 23 & 646 & 257.790 & -23.148417 & -44.246978 & This study \\
\hline 6 & Tinguá Biological Reserve & 25 & 1.504 & 268.473 & -22.596153 & -43.495839 & Lourenço et al., 2014 \\
\hline 7 & Guapiaçu Ecological Reserve & 24 & 1.236 & 116.640 & -22.400000 & -42.733333 & Souza et al., 2015 \\
\hline 8 & Rio das Pedras Ecological Reserve & 23 & 1.301 & - & -22.988928 & -44.104261 & Luz et al., 2011a \\
\hline 9 & Paraíso do Tobias* & 23 & 650 & 11.232 & -21.404500 & -42.067683 & Esbérard et al., 2010 \\
\hline 10 & Paraíso State Ecological Station & 22 & 824 & - & -22.489500 & -42.913972 & Esbérard, 2007 \\
\hline 11 & Marambaia Island & 22 & 746 & - & -22.939444 & -43.610556 & Lourenço et al., 2010 \\
\hline 12 & Morro de São João* & 21 & 1.056 & - & -22.538417 & -42.012472 & Esbérard et al., 2013 \\
\hline 13 & Pedra Branca State Park & 21 & 662 & - & -22.940556 & -43.480556 & Dias et al., 2002, 2003 \\
\hline 14 & Gipóia Island & 19 & 1.731 & - & -23.039058 & -44.353239 & Carvalho et al., 2011 \\
\hline 15 & Itacuruçá Island* & 19 & 1.128 & 89.400 & -22.940278 & -43.894444 & Gomes \& Esbérard, 2017 \\
\hline 16 & Rio de Janeiro Botanical Garden & 19 & 872 & - & -22.967683 & -43.223858 & Esbérard, 2003 \\
\hline 17 & Grajaú State Park & 19 & 547 & - & -22.923611 & -43.268333 & Esbérard, 2003 \\
\hline 18 & Tinguá Biological Reserve & 19 & 528 & - & -22.596153 & -43.495839 & Dias \& Peracchi, 2008 \\
\hline 19 & Serra da Bocaina National Park & 19 & 480 & 129.600 & -23.205277 & -44.838055 & Delciellos et al., 2018 \\
\hline 20 & Açude da Solidão & 18 & 484 & - & -22.961111 & -43.300277 & Esbérard, 2003 \\
\hline 21 & Serra da Tiririca State Park & 18 & 269 & - & -22.951147 & -43.008333 & Teixeira \& Peracchi, 1996 \\
\hline 22 & Morro Azul* & 17 & 796 & 89.700 & -22.484114 & -43.566667 & Pereira, 2013 \\
\hline 23 & Curió Natural Municipal Park & 17 & 732 & 51.840 & -22.596944 & -43.705833 & Gomes et al., 2015 \\
\hline 24 & Penhasco Dois Irmãos Natural Municipal Park & 17 & 527 & - & -22.989069 & -43.233997 & Esbérard, 2003 \\
\hline 25 & Gávea Park & 15 & 252 & - & -23.985555 & -43.248333 & Esbérard, 2003 \\
\hline 26 & Poço das Antas Biological Reserve & 14 & 2.557 & 68.040 & -22.554833 & -42.279883 & Mello, 2009 \\
\hline 27 & Mendanha Mountain Range & 14 & 466 & 63.000 & -22.825217 & -43.527389 & Menezes-Júnior, 2008 \\
\hline 28 & Prainha Natural Municipal Park & 14 & 384 & 15.900 & -23.033386 & -43.502700 & Pinto, 2008 \\
\hline 29 & Itatiaia National Park & 14 & 238 & 45.450 & -22.453917 & -44.605539 & Martins et al., 2015 \\
\hline 30 & Quinta da Boa Vista* & 13 & 2.994 & - & -22.905556 & -43.221222 & Esbérard et al., 2014 \\
\hline 31 & Araras Bological Reserve* & 13 & 746 & - & -22.445011 & -43.261539 & Esbérard et al., 1996 \\
\hline 32 & Trapicheiros Reserve & 13 & 538 & - & -22.941203 & -43.236022 & Esbérard, 2003 \\
\hline 33 & Serra dos Órgãos National Park* & 12 & 177 & 8.172 & -22.491136 & -43.043772 & Moratelli \& Peracchi, 2007 \\
\hline 34 & Restinga de Jurubatiba National Park & 11 & 115 & 19.140 & -22.204053 & -41.528261 & Luz et al., 2011b \\
\hline 35 & Visconde de Mauá & 10 & 166 & 10.135 & -22.363056 & -44.596519 & Luz et al., 2013 \\
\hline 36 & Rio Vermelho Farm & 10 & 108 & 7.560 & -22.721944 & -42.550833 & Mello \& Schittini, 2005 \\
\hline 37 & União Biological Reserve & 9 & 204 & 7.560 & -22.452678 & -42.041825 & Mello \& Schittini, 2005 \\
\hline 38 & Pedra Branca State Park & 9 & 164 & - & -22.940556 & -43.480556 & Almeida et al., 2011 \\
\hline 39 & Maricá Environmental Protection Area & 6 & 56 & 17.640 & -22.956111 & -42.882222 & Gomes et al., 2016 \\
\hline
\end{tabular}

* $=\quad$ Inventories with capture in refuges.

- $=$ Capture efforts in $\mathrm{h} . \mathrm{m}^{2}$ not available in publications.

in the surveys with highest capture efficiency. In studies 3,4 , and 5 , we did not choose specific points to set the mist nets. In study 3, the nets were set systematically, while in study 5 we used the method of uniform distribution plots. Only study 4 included sampling efforts in the tree canopy.

Comparisons between studies are of high relevance to science, contributing to the understanding of patterns of habitat use or even functioning as parameters of efficiency, especially when different methods are used. Setting mist nets in the forest canopy, the method used in study 4 , is an alternative to survey bat species not easily captured in nets set at ground level (e.g., Carvalho \& Fabián, 2011). Knowledge on the use of the canopy by bats is still incipient in Brazil (Scultori et al., 2008), where most studies of the kind have been conducted in the Amazon, often leading to the addition of exclusive species only registered when this method is applied (e.g., Kalko \& Handley, 2001; Bernard, 2001). Considering the chronology of studies on Ilha Grande, positioning mist nets at canopy height led to the addition of three species. Although the capture rates of $C$. auritus, $A$. cinereus and $P$. recifinus were low, these species are often captured at ground level, as in study 5 . Setting mist nets in the canopy increased the capture rate of species that might otherwise have been considered rare if surveys had been restricted to ground level (Esbérard et al., 2006; Bolzan et al., 2010).

Even if capture rate was already high in former years, study 5, the most recent one (from 2014 to 2018), 
contributed more species records to the list of Ilha Grande. The RAPELD methodology used in this study (Magnusson et al., 2005) recommends sampling to be carried out in areas away from human settlements or roads (where research is often conducted), removing the bias of where researchers believe capture rate will be higher. Adoption of this methodology directed sampling to be performed in areas not considered in former studies (Esbérard et al., 2006), as well as at higher altitudes.

Areas in the Atlantic Forest where records of bats varied from 20 to 40 species and more than 1,000 Phyllostomidae individuals were captured may be considered well studied (e.g., Esbérard, 2003; Bergallo et al., 2003). By applying these parameters to the studies assessed in this paper, we found that more than 20 species were only registered in nine studies in Rio de Janeiro state, while more than 1,000 Phyllostomidae bats were captured only in three of these nine studies (Lourenço et al., 2014; Souza et al., 2015; Luz et al., 2011a). Capture rate may be related to local bat density, but it can also be influenced by the methods used (Fleming, 1988; Kunz \& Kurta, 1988; Esbérard, 2006, 2007, 2009).

Long capture efforts are required to assess the real richness of a location (Voss \& Emmons, 1996; Bergallo et al., 2003). A large effort may be represented by the increase of survey nights and/or capture hours, or by the number and surface area of mist nets (Morrison, 1978, 1980 ,; Straube \& Bianconi, 2002). The two studies in Rio de Janeiro state that stand out due to a capture effort of more than 200,000 h. $\mathrm{m}^{2}$ are among the richest ( 25 and 23 species) (Lourenço et al., 2014; study 5 on llha Grande). Short inventories most often do not include species that are difficult to capture or that are considered rare; such species may be captured in long-term ecological studies or when higher capture efforts than usual are applied (Esbérard, 2009).

So that more consistent data for conservation studies are obtained (see Bernard et al., 2011), it is important that the lists are updated regularly, as new species are being described and registered as a result of taxonomic reviews and new inventories. (e.g., Moratelli et al., 2011; Nogueira et al., 2012; Dias et al., 2013; Nascimento et al., 2013; Delciellos et al., 2018). Lists of species that provide the capture quantity are important, as variation in abundance has been applied in species management and conservation biology (Brown et al., 1995).

\section{CONCLUSIONS}

Given the results of our study, we reiterate the relevance of specimen collection for vouchers in zoological collections. The analysis and confirmation of taxonomic identification of specimens a posteriori in the light of current knowledge depends on voucher specimens and is essential to increase the knowledge of species diversity in different areas. Bats captured on Ilha Grande and deposited in zoological collections allowed us to review the identification of specimens as well as to remove species whose identification had not been confirmed from the list of bat species of Ilha Grande.

Complementarily, Ihha Grande is a location with a long history of research with logistical support by the Center for Environmental Studies and Sustainable Development (CEADS, acronym in Portuguese) of the State University of Rio de Janeiro (UERJ, acronym in Portuguese), located in Dois Rios Village. This explains the number of studies conducted by different coordinators with various objectives described in this paper. It has also contributed to the fact that Ilha Grande is one of the areas in the state of Rio de Janeiro with more bat records in terms of abundance and species richness, as well as one of the areas with highest capture effort.

The use of capture effort measures may be considered efficient to compare species richness in the Phyllostomidae family. For comparisons between studies, however, the use of this variable alone may be a problem because the sampling design of the surveys will influence the total richness registered at the sampling site. When studies on llha Grande were compared with others in the state, we noticed variations in richness and in abundance due to the methods used, with some species exclusive to certain studies. Besides, several publications do not include capture effort data, or calculate capture effort differently from the recommendation by Straube \& Bianconi (2002), used in this study.

Implementation of the RAPELD methodology and taxonomic identification supported by voucher specimens in zoological collections made it possible to add new species records for Ilha Grande. Still, other new species records may be expected for the island, once sampling of bat species not commonly captured in mist nets has not been intensive. A methodology for insectivore bats, such as the use of bioacoustics, may increase the richness of bat species on Ilha Grande even more. In addition to the 36 species confirmed in this study, other four species for which voucher specimens were not available may be considered for Ilha Grande based on spatial distribution data.

\section{ACKNOWLEDGMENTS}

We thank the Centro de Estudos Ambientais e Desenvolvimento Sustentável (CEADS), Universidade do Estado do Rio de Janeiro (UERJ), and Instituto Estadual do Ambiente do Estado do Rio de Janeiro (INEA) for logistical support for the present study. We also thank the members of the Laboratório de Ecologia de Mamíferos (LEMA) for support in fieldwork. L.M.C. and E.C.L. thank Coordenação de Aperfeiçoamento de Pessoal de Nível Superior (CAPES) and Fundação de Amparo à Pesquisa do Estado do Rio de Janeiro (FAPERJ) for a postdoctoral grant and for funding the study (E-26/101.399/2014; E-26/202.158/2015). C.E.L.E. received grants from CNPq (301061/2007-6). H.G.B. thanks FAPERJ for a CNE Grant (E-26/202.757/2017), and Prociência/UERJ and Conselho Nacional de Desenvolvimento Científico e Tecnológico (CNPq) (307781/2014-3) for research and productivity 
grants. This study is part of the"Programa de Pesquisas em Biodiversidade da Mata Atlântica (PPBio Mata Atlântica Network)" of the Ministry of Science, Technology, Innovation and Communications (MCTIC) and was supported by Conselho Nacional de Desenvolvimento Científico e Tecnológico (CNPq) (457458/2012-7).

\section{AUTHORS' CONTRIBUTIONS}

Each author made a relevant contribution to the present manuscript, performed a critical revision, and approved the final version. L.M.C.: Fieldwork (in charge of study 5 on Ilha Grande); organization, analysis and data interpretation; manuscript development. E.C.L.: Fieldwork (study 5 on Ilha Grande); organization, data analysis and interpretation; manuscript development. D.A.D.J.: Fieldwork (study 5 on Ilha Grande); organization, analysis and data interpretation; manuscript development. D.D.: Taxonomic identification of voucher specimens; manuscript development. C.E.L.E.: Fieldwork (studies 1 and 2 on Ilha Grande); manuscript development. T.J.-N.: Fieldwork (study 3 and in charge of study 4 on Ilha Grande); organization of data. G.M.: Fieldwork (in charge of studies 1, 2, and 3 on Ilha Grande); organization of data. H.G.: Fieldwork (studies 1 and 2 on Ilha Grande); data analysis and interpretation; manuscript development.

\section{REFERENCES}

Almeida, J.C.; Silva, S.S.P.; Serra-Freire, N.M. \& Valim, M.P. 2011. Ectoparasites (Insecta and Acari) Associated with Bats in Southeastern Brazil. Morphology, Systematics, Evolution, 48(4): 753-757. D01

Araújo, D.S.D. \& Oliveira, R.R. 1988. Reserva Biológica Estadual da Praia do Sul (Ilha Grande, Estado do Rio de Janeiro). Lista Preliminar da Flora. Acta Botanica Brasilica, 1: 83-94. DOI

Bergallo, H.G.; Esbérard, C.E.L.; Mello, M.A.R.; Lins, V.; Mangolin, R.; Melo, G.G.S. \& Baptista, M. 2003. Bat species richness in atlantic forest: what is the minimum sampling effort? Biotropica, 35(2): 278-288. DOI

Bernard, E. 2001. Vertical stratification of bat communities in primary forests of Central Amazon, Brazil. Journal of Tropical Ecology, 17: 115-126. D01

Bernard, E.; Aguiar, L.M.S \& Machado, R.B. 2011. Discovering the Brazilian bat fauna: a task for two centuries? Mammal Review, 41:23-39. D0I

Blackburn, T.M. \& Gaston KJ. 1998. Some methodological issues in macroecology. American Naturalist, 151: 68-83. D0I

Bolzan, D.P.; Lourenço, E.C.; Costa L.M.; Luz, J.L.; Nogueira, T.J.; Dias, D.; Esbérard, C.E.L. \& Peracchi, A.L. 2010. Morcegos da região da Costa Verde e adjacências, litoral sul do Estado do Rio de Janeiro. Chiroptera Neotropical, 16(1): 585-594. https://www.bvs-vet.org.br/vetindex/ periodicos/chiroptera-neotropical/16-(2010)-1/morcegos-da-regiaoda-costa-verde-e-adjacencias-litoral-sul-do-estado-.

Bonaccorso, F.J. \& Smythe, N. 1972. Punch-Marking Bats: An Alternative to Banding. Journal of Mammalogy, 53(2): 389-390. DOI

Brito, D.; Oliveira, L.C.; Oprea, M. \& Mello, M.A.R. 2009. An overview of Brazilian mammalogy: trends, biases and future directions. Revista Brasileira de Zoologia, 26: 67-73. D0I

Brown, J.H.; Mehlman, D. \& Stevens, G. 1995. Spatial variation in abundance. Ecology, 76(7): 2028-2043. D0I
Carvalho, F. \& Fabián, M.E. 2011. Método de elevação de redes de neblina em dosséis florestais para amostragem de morcegos. Chiroptera Neotropical, 17(1): 795-802. https://www.bvs-vet.org.br/vetindex/periodicos/ chiroptera-neotropical/17-(2011)-1/metodo-de-elevacao-de-redesde-neblina-em-dosseis-florestais-para-amos.

Carvalho, W.D.; Freitas, L.N.; Freitas, G.P.; Luz, J.L.; Costa, L.M. \& Esbérard, C.E.L. 2011. Efeito da chuva na captura de morcegos em uma ilha da costa sul do Rio de Janeiro, Brasil. Chiroptera Neotropical, 17: 808-816. https://www.bvs-vet.org.br/vetindex/periodicos/chiropteraneotropical/17-(2011)-1/efeito-da-chuva-na-captura-de-morcegosem-uma-ilha-da-costa-sul-do-rio.

Costa, L.M.; Luz, L.J.; Esbérard, C.E.L. 2012. Riqueza de morcegos insetívoros em lagoas no estado do Rio de Janeiro, Brasil. Papéis Avulsos de Zoologia, 52(2): 7-19. DOI

Delciellos, A.C.; Motta, A.; Dias, D.; Almeida, B. \& Rocha-Barbosa, 0. 2018. Bats of the Serra da Bocaina National Park, southeastern Brazil: an update species list and distribution extension for Trinycteris nicefori (Sanborn, 1949). Biota Neotropica, 18(4): e20180537. DOI

Dias, D. \& Peracchi, A.L. 2008. Quirópteros da Reserva Biológica do Tinguá, estado do Rio de Janeiro, sudeste do Brasil (Mammalia: Chiroptera). Revista Brasileira de Zoologia, 25(2): 333-369. D0I

Dias, D.; Carvalho, W.D.; Teixeira, T.S.M.; Tavares, D.; Xavier, B.S.; Valle, E.L.V. \& Esbérard, C.E.L. 2015. First record of Myotis izecksohni (Chiroptera, Vespertilionidae) for the Atlantic Forest of Minas Gerais, Southeastern Brazil. Mastozoologia Neotropical, 22: 149-153. http://www.scielo.org. ar/scielo.php?script=sci arttext\&pid=S0327-93832015000100015.

Dias, D.; Esbérard, C.E.L. \& Moratelli, R. 2013. A new species of Lonchophylla (Chiroptera, Phyllostomidae) from the Atlantic Forest of southeastern Brazil, with comments on L. bokermanni. Zootaxa, 3722: 347-360. D0I

Dias, D.; Silva, S.S.P. \& Peracchi, A.L. 2002. Quirópteros do Parque Estadual da Pedra Branca, Rio de Janeiro, RJ (Mammalia; Chiroptera). Revista Brasileira de Zoologia, 19: 113-140. DOI

Dias, D.; Silva, S.S.P. \& Peracchi, A.L. 2003. Ocorrência de Glyphonycteris sylvestris Thomas (Chiroptera, Phyllostomidae) no Estado do Rio de Janeiro, Sudeste do Brasil. Revista Brasileira de Zoologia, 20(2): 365-366. DOI

Emmons, L.H. \& Feer, F. 1997. Neotropical rainforest mammals: a field guide. 2 ed. Chicago, University of Chicago Press. 380p.

Esbérard, C.E.L. 2003. Diversidade de morcegos em área de Mata Atlântica regenerada no sudeste do Brasil. Revista Brasileira de Zoociências, 5(2): 189-204. https://periodicos.ufjf.br/index.php/zoociencias/article/ view/24216.

Esbérard, C.E.L. 2006. Efeito da coleta de morcegos por noites seguidas no mesmo local. Revista Brasileira de Zoologia, 23(4): 1093-1096. D0I

Esbérard, C.E.L. 2007. Influência do ciclo lunar na captura de morcegos Phyllostomidae. Iheringia, Série Zoologia, 97(1): 81-85. D01

Esbérard, C.E.L. 2009. Capture sequence and relative abundance of bats during surveys. Revista Brasileira de Zoologia, 26(1): 103-108. DOI

Esbérard, C.E.L.; Baptista, M.; Costa, L.M.; Luz, J.L. \& Lourenço, E.C. 2010. Morcegos de Paraíso do Tobias, Miracema, Rio de Janeiro. Biota Neotropica, 10(4): 249-255. D0I

Esbérard, C.E.L.; Chagas, A.S.; Baptista, M. \& Luz, E.M. 1996. Levantamento de Chiroptera na Reserva Biológica de Araras, Petrópolis, Rio de Janeiro - I - riqueza de espécies. Revista Científica do Centro de Pesquisas Gonzaga da Gama Filho, 2: 65-87. https://www.academia.edu/1104055/ Levantamento de Chiroptera na Reserva Biológica de Araras Petrópolis RJ.

Esbérard, C.E.L.; Costa, L.M. \& Luz, J.L. 2013. Morcegos de Morro de São João, Estado do Rio de Janeiro, Sudeste do Brasil. Bioscience Journal, 29(2): 449-457. DOl. 
Esbérard, C.E.L.; Jordão-Nogueira, T.; Luz, J.L.; Melo, G.G.S.; Mangolin, R.; Jucá, N.; Raíces, D.S.; Enrici, M.C. \& Bergallo, H.G. 2006. Morcegos da Ilha Grande, Angra dos Reis, RJ, Sudeste do Brasil. Revista Brasileira de Zoociências, 8: 151-157. https://periodicos.ufjf.br/index.php/ zoociencias/article/view/24115.

Esbérard, C.E.L.; Luz, J.L.; Costa, L.M. \& Bergallo, H.G. 2014. Bats (Mammalia, (hiroptera) of an urban park in the metropolitan area of Rio de Janeiro, southeastern Brazil. Iheringia, Série Zoologia, 104: 59-69. D0I

Estrada, A.; Jiménez, C.; Rivera, A. \& Fuentes, E. 2004. General bat activity measured with an ultrasound detector in a fragmented tropical landscape in Los Tuxtlas, Mexico. Animal Biodiversity and Conservation, 27: 1-9. http://abc.museucienciesjournals.cat/files/ABC-27-2-pp-5-13.pdf.

Fernandez, F.A.S.; Cerqueira, R. \& Tribe, C.J. 1988. On the mammals collected on coastal islands of the Rio de Janeiro, Brazil. Mammalia, 52(2): 219-224. D0I

Fleming, T.H. 1988. The short-tailed fruit bat. Chicago, University of Chicago Press. Garbino, G.S.T.; Gregorin, R.; Lima, I.P.; Loureiro, L.; Moras, L.M.; Moratelli, R.; Nogueira, M.R.; Pavan, A.C.; Tavares, V.C. \& Peracchi, A.L. 2020. Updated checklist of Brazilian bats: versão 2020. Comitê da Lista de Morcegos do Brasil (CLMB). Sociedade Brasileira para o Estudo de Quirópteros (Sbeq). Available: https://www.sbeq.net/lista-de-especies. Access: 12/09/2020.

Gardner, A.L. 2008. Family Phyllostomidae Gray, 1825. In: Gardner, A.L. (Ed.). Mammals of South America, Vol. 1, Marsupials, xenarthrans, shrews, and bats. Chicago Press. p. 207-208.

Gomes, L.A.C. \& Esbérard, C.E.L. 2017. Long-term bat study on an island in the southeastern Brazilian coast with comparison of richness and composition of species among sites. Studies on Neotropical Fauna and Environment, 52(1): 43-52. D01

Gomes, L.A.C.; Maas, A.C.S.; Martins, M.A.; Pedrozo, A.R.; Araújo, R.M. \& Peracchi, A.L. 2016. Morcegos em área de restinga de unidade de conservação no estado do Rio de Janeiro, sudeste do Brasil. Neotropical Biology and Conservation, 11(1): 31-37. D0I

Gomes, L.A.C.; Pires, A.S.; Martins, M.A.; Lourenço, C.L. \& Peracchi, A.L. 2015. Species composition and seasonal variation in abundance of Phyllostomidae bats (Chiroptera) in an Atlantic Forest remnant, southeastern Brazil. Mammalia, 79(1): 61-68. https://www.degruyter. com/view/journals/mamm/79/1/article-p61.xml.

Gregorin, R. \& Taddei, V.A. 2002. Chave artificial para a identificação de Molossídeos brasileiros (Mammalia, Chiroptera). Mastozoología Neotropical, 9(1): 13-32.

Hammer, 0.; Harper, D.A.T. \& Ryan, P.D. 2001. PAST: Paleontological statistics software package for education and data analysis. Paleontologia Electronica, 4(1): unpaginated. Available: http://palaeo-electronica. org/2001 1/past/issue1 01.htm. Access: 11/10/2019.

Humphrey, P.S.; Bridge, D. \& Lovejoy, T.E. 1968. A technique for mist-netting in the forest canopy. Bird-Banding, 39(1): 43-50. https://sora.unm.edu/ sites/default/files/journals/jfo/v039n01/p0043-p0050.pdf.

Instituto Estadual do Ambiente (INEA). 2013. Parque Estadual da Ilha Grande: plano de manejo (fase 2)/resumo executivo/Instituto Estadual do Ambiente. Rio de Janeiro, INEA. http://www.inea.ri.gov.br/wp-content/ uploads/2019/01/PEIG-RM.pdf.

Instituto Estadual do Ambiente (INEA). 2020. Parque Estadual da Ilha Grande. Available: http://www.inea.ri.gov.br/cs/groups/public/documents/ document/zwew/mdi2/ edisp/inea0026733.pdf. Access: 18/05/2020.

Kalko,E.K.V.1998.Organizationanddiversityoftropicalbatscommunitiesthrough space and time. Zoology, 111(4): 281-297. https://www.scienceopen. com/document?vid=34f186db-f2f5-457d-a93b-2ff09067934b.

Kalko, E.K.V. \& Handley, C.0. 2001. Neotropical bats in the canopy: diversity, community structure, and implications for conservation. Plant Ecology, 153(1-2): 319-333. DOI
Kunz, T.H. \& Kurta, A. 1988. Capture methods and holding devices. In: Kunz, T.H. (Ed.). Ecological and behavioral methods for the study of bats. Washington, D.C., Smithsonian Institution Press. p. 1-29.

Lewinsohn, T.M. \& Prado, P.I. 2005. Quantas espécies há no Brasil? Megadiversidade, 1(1): 36-42. https://www.researchgate.net/ publication/271644747 Quantas especies ha no Brasil.

López-González, C.; Presley, S.J.; Owen, R.D. \& Willig, M.R. 2001. Taxonomic status of Myotis (Chiroptera: Vespertilionidae) in Paraguay. Journal of Mammalogy, 82(1): 138-160. DOI

Lourenço, C.P.; Gomes, L.A.C.; Pinheiro, M.C.; Patrício, P.M.P. \& Famadas, K.M. 2014. Compositions of bat assemblages (Mammalia: Chiroptera) in tropical riparian forests. Zoologia, 31(4): 361-369. D0I

Lourenço, E.C.; Costa, L.M.; Silva, R.M.; Esbérard, C.E.L. 2010. Bat diversity of llha da Marambaia, southern Rio de Janeiro State, Brazil (Chiroptera, Mammalia). Revista Brasileira de Biologia, 70(3): 511-519. D0I

Luz, J.L.; Costa, L.M.; Jordão-Nogueira, T.; Esbérard, C.E.L. \& Bergallo, H.G. 2013. Morcegos em área de Floresta Montana, Visconde de Mauá, Resende, Rio de Janeiro. Biota Neotropica, 13(2): 1-6. D01

Luz, J.L.; Costa, L.M.; Lourenço, E.C. \& Esbérard, C.E.L. 2011a. Morcegos (Mammalia, Chiroptera) da Reserva Rio das Pedras, Rio de Janeiro, Sudeste do Brasil. Biota Neotropica, 11(1): 95-101. DOI

Luz, J.L.; Mangolin, R.; Esbérard, C.E.L. \& Bergallo, H.G. 2011b. Morcegos (Chiroptera) capturados em lagoas do Parque Nacional da Restinga de Jurubatiba, Rio de Janeiro, Brasil. Biota Neotropica, 11(4): 161-168. D0I

Magnusson, W.E.; Lima, A.P.; Luizão, R.; Luizão, F.; Costa, F.R.C.; Castilho, C.V. \& Kinupp, V.F. 2005. RAPELD: A modification of the Gentry method for biodiversity surveys in Long-Term Ecological Research Sites. Biota Neotropica, 5(2): 1-6. DOI

Martins, M.A.; Carvalho, W.D.; Dias, D.; França, D.S.; Oliveira, M.B. \& Peracchi, A.L. 2015. Bat species richness (Mammalia, Chiroptera) along an elevational gradient in the Atlantic Forest of Southeastern Brazil. Acta Chiropterologia, 17(2): 401-409. DOI

Mello, M.A.R. 2009. Temporal variation in the organization of a Neotropical assemblage of leaf-nosed bats (Chiroptera: Phyllostomidae). Acta Oecologica, 35: 280-286. DOI

Mello, M.A.R. \& Schittini, G.M. 2005. Ecological Analysis of three bat assemblages from conservation units in the lowlandatlantic forest of Rio de Janeiro, Brazil. Chiroptera Neotropical, 11(1-2): 206-210.

Menezes-Júnior, L.F. 2008. Morcegos da Serra do Mendanha, Rio de Janeiro, RJ, Brasil (Mammalia, Chiroptera). Masters Dissertation. Universidade Federal Rural do Rio de Janeiro.

Moratelli, R. \& Peracchi, A.L. 2007. Morcegos (Mammalia, Chiroptera) do Parque Nacional da Serra dos Órgãos. In: Cronemberger, C. \& Castro, E.B.V. (Orgs.). Ciência e Conservação na Serra dos Órgãos. Brasília, IBAMA. p. 193-210.

Moratelli, R.; Peracchi, A.L.; Dias, D. \& Oliveira, J.A. 2011. Geographic variation in South American populations of Myotis nigricans (Schinz, 1821) (Chiroptera, Vespertilionidae), with the description of two new species. Mammalian Biology, 76(5): 592-607. D01

Morrison, D.W. 1978. Foraging ecology and energetics of the frugivorous bat Artibeus jamaicensis. Ecology, 59(4): 716-723. DOI

Morrison, D.W. 1980. Foraging and day-roosting dynamics of canopy fruit bats in Panama. Journal of Mammalogy, 61: 20-29. DOI

Muylaert, R.L.; Stevens, R.D.; Esbérard, C.E.L.; Mello, M.A.R.; Garbino, G.S.T.; Varzinczak, L.H.; Faria, D.; Weber, M.M.; Rogeri, P.K.; Regolin, A.L.; Oliveira, Hernani, F.M.; Costa, L.M.; Barros, M.A.S.; Sabino-Santos-Jr., G.; Morais, M.A.C.; Kavagutti, V.S.; Passos, F.C.; Marjakangas, Emma-Liina; Maia, F.G.M.; Ribeiro, M.C. \& Galetti, M. 2017. Atlantic Bats: a data set of bat communities from the Atlantic Forests of South America. Ecology, 98(12): 3227. DOI 
Myers, N.; Mittermeier, R.A.; Mittermeier, C.G.; Fonseca, G.A.B. \& Kent, J. 2000. Biodiversity hotspots for conservation priorities. Nature, 403(6772): 853-845.

Nascimento, M.C.; Dias, L.H.; Gregorin, R. \& Lessa, G. 2013. Rediscovery of Lonchophylla bokermanni Sazima, Vizotto and Taddei, 1978 (Chiroptera: Phyllostomidae: Lonchophyllinae) in Minas Gerais, and new records for Espírito Santo, southeastern Brazil. Check List, 9(5): 1046-1049. D0I

Nogueira, M.R.; Lima, I.P.; Peracchi, A.L. \& Simmons, N.B. 2012. New Genus and Species of Nectar-Feeding Bat from the Atlantic Forest of Southeastern Brazil (Chiroptera: Phyllostomidae: Glossophaginae). American Museum Novitates, 3747: 1-30. D0I

Nogueira, M.R.;Peracchi, A.L.\& Moratelli, R. 2007. Subfamília Phyllostominae. In: Reis, N.R.; Peracchi, A.L.; Pedro, W.A. \& Lima, I.P. Morcegos do Brasil. Londrina, Nelio R. dos Reis. p. 61-97.

Owen, R.D. 2000. La importancia de los inventarios cuantitativos en la conservation de la fauna silvestre. In: Cabrera, E.; Mercolli, C. \& Resquin, R. (Eds.). Manejo de fauna silvestre en Amazonia y latinoamerica. Asuncion, Paraguay, Fundacion Moises Bertoni. p. 15-28.

Pedro, W.A. \& Taddei, V.A. 1997. Taxonomic assemblage of bats from Panga Reserve, southeastern Brazil: abundance patterns and trophic relations in the Phyllostomidae (Chiroptera). Boletim do Museu de Biologia Mello Leitão, 6: 3-21. http://boletim.sambio.org.br/pdf/06 01.pdf.

Peracchi, A.L. \& Nogueira, M.R. 2010. Lista anotada dos morcegos do Estado do Rio de Janeiro, sudeste do Brasil. Chiroptera Neotropical, 16(1): 508-519. https://www.bvs-vet.org.br/vetindex/periodicos/chiropteraneotropical/16-(2010)-1/lista-anotada-dos-morcegos-do-estado-dorio-de-janeiro-sudeste-do-bras.

Pereira, S.N. 2013. Inventário e aspectos biológicos de quirópteros (Mammalia, (hiroptera) da localidade de Morro Azul, Engenheiro Paulo de Frontin, RJ. Masters Dissertation. Universidade Federal Rural do Rio de Janeiro.

Pinto, A.C.D. 2008. Comunidade de Quirópteros (Mammalia, Chiroptera) do Parque Natural Municipal da Prainha, Rio de Janeiro, RJ, Brasil. Masters Dissertation. Universidade Federal Rural do Rio de Janeiro.

Reis, N.R.; Fregonezi, M.N.; Peracchi, A.L. \& Shibatta, 0.A. 2013. Morcegos do Brasil - Guia de Campo. Rio de Janeiro, Technical Books.

Reis, N.R.; Peracchi A.L.; Pedro W.A. \& Lima, I.P. 2007. Morcegos do Brasil. Londrina, Nélio R. dos Reis.

Remsen, J.V. 1994. Use and misuse of bird lists in community ecology and conservation. Auk, 111: 225-227. DOI
Santos, A.J. 2003. Estimativas de riqueza em espécies. In: Cullen, J.R.; Rudran, R. \& Valadares-Padua, C. (Eds.). Métodos de estudos em biologia da conservação e manejo da vida silvestre. Editora da UFRP, Fundação 0 Boticário de Proteção à Natureza, Curitiba, 19-41.

Scultori, C.; Von Matter, S.; Peracchi, A.L. 2008. Métodos de amostragem de morcegos em subdossel e dossel florestal, com ênfase em redes de neblina. In: Reis, N.R.; Peracchi, A.L. \& Santos, G.A.S.D. (Eds.). Ecologia de Morcegos. Editora Londrina, Technical Books. p. 17-32.

Silveira, L.F.; Beisiegel, B.D.M.; Curcio, F.F.; Valdujo, P.H.; Dixo, M.; Verdade, V.K. \& Cunningham, P.T.M. 2010. What use do fauna inventories serve. Estudos Avançados, 24(68): 173-207. https://www.scielo.br/pdf/ea/ v24n68/en 15.pdf.

Simmons, N.B. \& Voss, R.S. 1998. The mammals of Paracou, French Guiana: a neotropical lowland rainforest fauna. Part I. Bats. Bulletin of the American Museum of Natural History, 273: 1-219. D0I

Sipinski, E.A.B. \& Reis, N.R. 1995. Dados ecológicos dos quirópteros da Reserva de Volta Velha, Itapoá, Santa Catarina, Brasil. Revista Brasileira de Zoologia, 12(3): 519-528. DOI

Souza, R.F; Novaes, R.L.M.; Siqueira, A.C.; Jacob, C.S.G.; Santos, C.E.L.; Feliz, S.; Ribeiro, E.; Sant'anna, C.; Vrcibradic, D.; Avilla, L.S.; Sbragia, I. \& Santori, R.T. 2015. Morcegos (Mammalia, Chiroptera) em remanescente de Floresta Atlântica, Rio de Janeiro, sudeste do Brasil. Neotropical Biology and Conservation, 10(1): 9-14. DOI

Stevens, R.D. 2013. Gradients of Bat Diversity in Atlantic Forest of South America: Environmental Seasonality, Sampling Effort and Spatial Autocorrelation. Biotropica, 45(6): 764-770. D0I

Straube, F.C. \& Bianconi, G.V. 2002. Sobre a grandeza e a unidade utilizada para estimar esforço de captura com utilização de rede-de-neblina. Chiroptera Neotropical, 8(1-2): 150-152.

Teixeira, S.C. \& Peracchi, A.L. 1996. Morcegos do Parque Estadual da Serra da Tiririca, Rio de Janeiro, Brasil (Mammalia, Chiroptera). Revista Brasileira de Zoologia, 13(1): 61-66. D0I

Vecchi, M.B. \& Alves, M.A.S. 2015. Bird assemblage mist-netted in an Atlantic Forest area: a comparison between vertically-mobile and ground-level nets. Brazilian Journal of Biology, 75(3): 742-751. D0I

Voss, R.S. \& Emmons, L.H. 1996. Mammalian diversity in neotropical lowland rainforests: a preliminary assessment. Bulletin of the American Museum of Natural History, 230: 1-115. http://digitallibrary.amnh.org/ handle/2246/1671. 